\title{
Mystery Case: Missed diagnosis of hereditary hemorrhagic telangiectasia presenting with recurrent ischemia
}

Waleed Brinjikji, MD, Christopher P. Wood, MD, and Vivek N. Iyer, MD

Neurology ${ }^{\circledR}$ 2019;92:1068-1069. doi:10.1212/WNL.0000000000007568
Correspondence

Dr. Brinjikji

Brinjikji.waleed@mayo.edu

Figure A 35-year-old woman with recurrent strokes

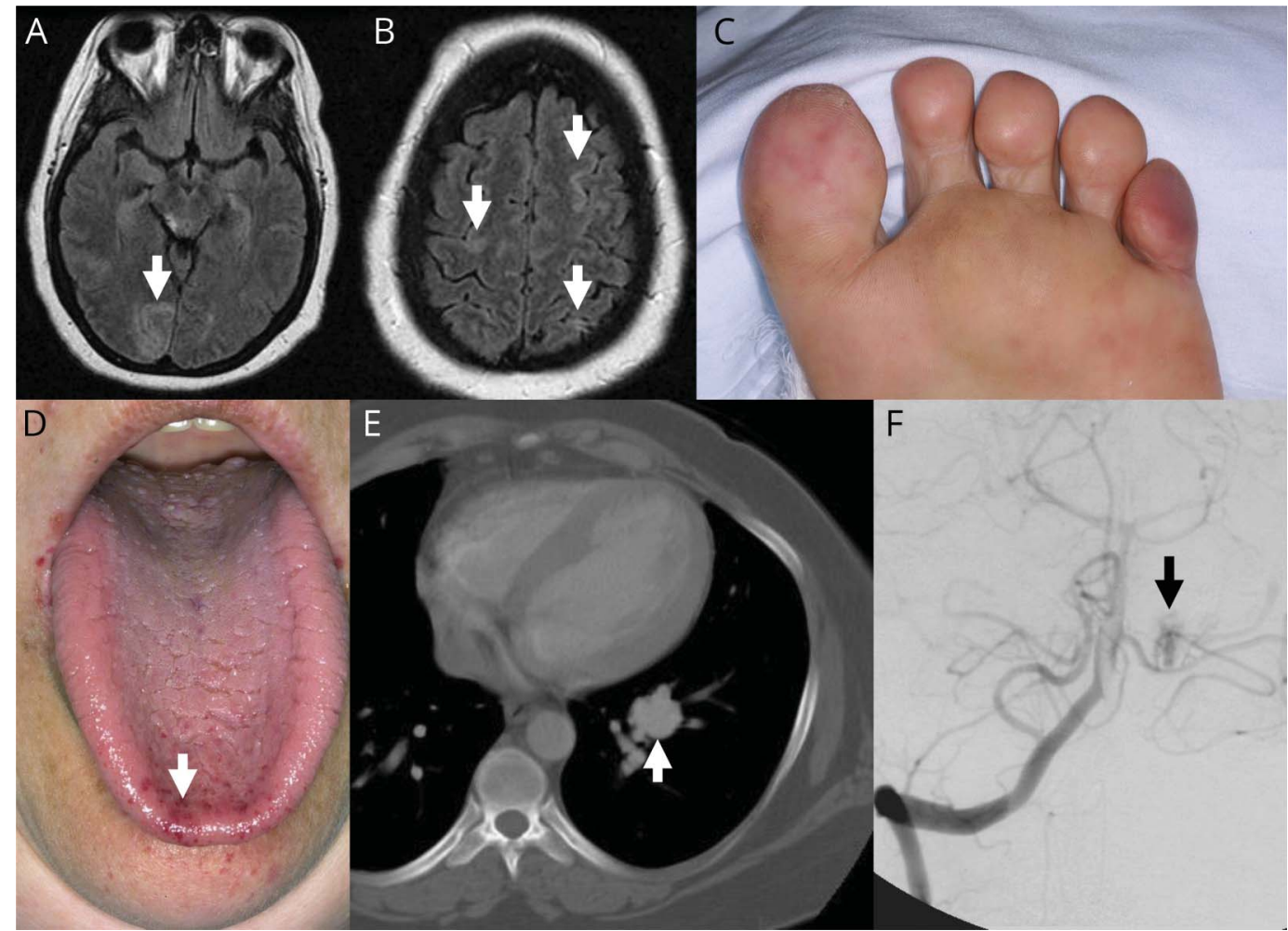

(A, B) T2/fluid-attenuated inversion recovery MRI shows subacute infarct in medial right occipital lobe and bilateral frontoparietal cortices. (C) Photograph of bluish discoloration of left fifth and first toes. (D) Photograph of lingual mucocutaneous telangiectasias. (E) CT angiography demonstrates large left lower lobe pulmonary arterial-venous malformation (AVM). (F) Small left cerebellar AVM on angiography.

A 35-year-old patient presented with hemianopia, decreased consciousness, and bilateral cortical foci of restricted diffusion (figure). Investigations for migraine, vasculitis, and cardiogenic stroke were negative. Four months later, the patient developed left foot claudication and discoloration. She was found to have lingual mucocutaneous telangiectasias and epistaxis. Further workup revealed pulmonary and cerebral arterial-venous malformations (AVMs). The patient met 3/4 Curacao criteria and had a definite hereditary hemorrhagic telangiectasia (HHT) diagnosis. Paradoxical emboli were the cause of her infarcts and lower extremity ischemia.

\section{MORE ONLINE}

Survey and results

NPub.org/mc9222 
HHT is an easily underdiagnosed cause of ischemic stroke in young adults. Delayed diagnosis results in recurrent but preventable peripheral and neurologic ischemic events.

\section{Mystery Case Responses}

The Mystery Case series was initiated by the Neurology ${ }^{\circledR}$ Resident \& Fellow Section to develop the clinical reasoning skills of trainees. Residency programs, medical student preceptors, and individuals were invited to use this Mystery Case as an educational tool. Responses were solicited through a group email sent to the American Academy of Neurology Consortium of Neurology Residents and Fellows and through social media.

Fifty-five percent of respondents correctly identified the main radiographic abnormality of subacute medial right occipital lobe infarcts. Sixteen percent of respondents correctly identified the more subtle subacute bilateral frontoparietal lobe infarcts. Sixty-seven percent of respondents correctly concluded that the underlying diagnosis was HHT. The majority (52.6\%) of respondents accurately stated that this is an autosomal dominant disorder. The only completely correct answer came from Dr. Reza Bavarsad Shahripour (Neurology Resident, The University of Tennessee Health Science Center).

This Mystery Case illustrates a rare and therefore commonly missed etiology for ischemic stroke in young adults. Further, this case highlights the importance of systemic features that are part of the diagnostic criteria for HHT known as the Curacao criteria. ${ }^{1}$ The Curacao criteria include (1) epistaxis, (2) family history, (3) telangiectasias, and (4) visceral lesions such as pulmonary, hepatic, spinal, or cerebral AVMs. Patients who meet at least 3 of the 4 criteria are classified as definite HHT. This patient had definite HHT because she met 3 out of 4 of the criteria based on epistaxis, lingual mucocutaneous telangiectasias, and both pulmonary and cerebral AVMs.

Ariel M. Lyons-Warren, MD, PhD

Baylor College of Medicine, Texas Children's Hospital, Houston

\section{Study funding}

No targeted funding reported.

\section{Disclosure}

The authors report no disclosures relevant to the manuscript. Go to Neurology.org/N for full disclosures.

\begin{tabular}{llll} 
Appendix Authors & & \\
\hline Name & Location & Role & Contribution \\
\hline $\begin{array}{l}\text { Waleed } \\
\text { Brinjikji, MD }\end{array}$ & $\begin{array}{l}\text { Mayo Clinic, } \\
\text { Rochester, } \\
\text { MN }\end{array}$ & Author & $\begin{array}{l}\text { Designed and conceptualized } \\
\text { study, drafted manuscript }\end{array}$ \\
$\begin{array}{llll}\text { Christopher } \\
\text { P. Wood }\end{array}$ & $\begin{array}{l}\text { Mayo Clinic, } \\
\text { Rochester, } \\
\text { MN }\end{array}$ & Author & $\begin{array}{l}\text { Designed and conceptualized } \\
\text { study, reviewed manuscript }\end{array}$ \\
\hline $\begin{array}{l}\text { Vivek N. Iyer } \\
\text { Mayo Clinic, } \\
\text { Rochester, } \\
\text { MN }\end{array}$ & Author & $\begin{array}{l}\text { Designed and conceptualized } \\
\text { study, reviewed manuscript }\end{array}$ \\
& & &
\end{tabular}

\section{Reference}

1. Chung MG. Hereditary hemorrhagic telangiectasia. Handb Clin Neurol 2015;132: $185-197$.

\section{Disputes \& Debates: Rapid online correspondence}

The editors encourage comments on recent articles through Disputes \& Debates:

Access an article at Neurology.org/ $N$ and click on "COMMENT" beneath the article header. Responses will be posted within 3 business days.

Before submitting a comment to Disputes \& Debates, remember the following:

- Disputes \& Debates is restricted to comments about studies published in Neurology within the last eight weeks

- Read previously posted comments; redundant comments will not be posted

- Your submission must be 200 words or less and have a maximum of five references; reference one must be the article on which you are commenting

- You can include a maximum of five authors (including yourself) 


\section{Neurology}

\section{Mystery Case: Missed diagnosis of hereditary hemorrhagic telangiectasia presenting with recurrent ischemia}

Waleed Brinjikji, Christopher P. Wood and Vivek N. Iyer

Neurology 2019;92;1068-1069

DOI 10.1212/WNL.0000000000007568

This information is current as of May 27, 2019

\section{Updated Information \& Services}

References

Subspecialty Collections

Permissions \& Licensing

Reprints including high resolution figures, can be found at: http://n.neurology.org/content/92/22/1068.full

This article cites 1 articles, 0 of which you can access for free at: http://n.neurology.org/content/92/22/1068.full\#ref-list-1

This article, along with others on similar topics, appears in the following collection(s):

\section{Embolism}

http://n.neurology.org/cgi/collection/embolism

Stroke in young adults

http://n.neurology.org/cgi/collection/stroke_in_young_adults

Information about reproducing this article in parts (figures,tables) or in its entirety can be found online at:

http://www.neurology.org/about/about_the_journal\#permissions

Information about ordering reprints can be found online:

http://n.neurology.org/subscribers/advertise

Neurology ${ }^{\circledR}$ is the official journal of the American Academy of Neurology. Published continuously since 1951, it is now a weekly with 48 issues per year. Copyright @ 2019 American Academy of Neurology. All rights reserved. Print ISSN: 0028-3878. Online ISSN: 1526-632X.

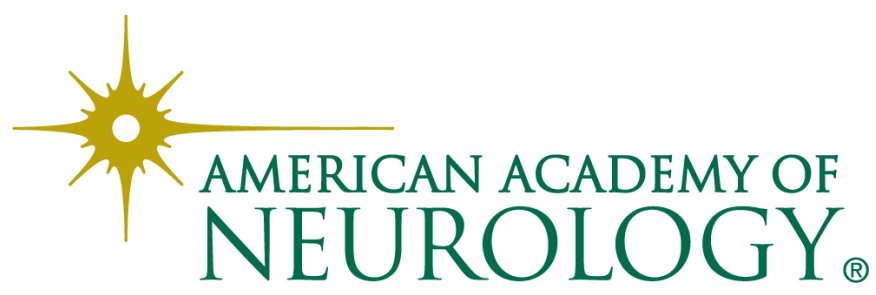

